\title{
Mikrobiális anyagcsere aktivitás-mintázat és mikorrhiza gomba kolonizáció elemzése három szikes tó melletti talaj rizoszférában
}

\author{
${ }^{1}$ SZILI-KovÁCs Tibor, ${ }^{2}$ BÁRÁNY Ágnes, ${ }^{1}$ FÜZY Anna, ${ }^{1}$ TAKÁCs Tünde, ${ }^{1,2}$ KretT Gergely, \\ ${ }^{1}$ KovÁcs Ramóna és ${ }^{2}$ BORSODI Andrea \\ ${ }^{1}$ MTA Agrártudományi Kutatóközpont, Talajtani és Agrokémiai Intézet, Budapest \\ ${ }^{2}$ ELTE TTK Mikrobiológiai Tanszék, Budapest
}

A szikes talajok hazai szakirodalma rendkívül gazdag (TóTH \& SZENDREI 2006), ugyanakkor mikrobiológiai vizsgálatok elsősorban szikes tavakból történtek (SZABÓ et al. 2004, BORSODI et al. 2005, RUSZNYÁK et al. 2008), talajmikrobiológiai vizsgálatokról nagyon kevés tanulmány készült (FüZY et al. 2008). A szikes talajok sajátosságai közül a nagy sótartalom és alkalikus kémhatás, amelyek elsősorban a dunavölgyi szikes területeken jelentkeznek markánsan, a mikroorganizmusok alkalmazkodását is alaposan próbára teszik. Ráadásul az ingadozó hőmérséklet és vízjárás, a kiszáradástól az időszakos vízborításokig tovább fokozzák a környezeti szélsőségeket. Vizsgálatainkat 2013-ban kezdtük a Kiskunsági Nemzeti Park szikes területein, amelynek első eredményeit már közöltük (BÁRÁNY et al. 2014; BORSODI et al. 2015).

A talajok illetve a talajban lévő mikrobiális együttes anyagcsere (katabolikus) aktivitás-mintázatán alapuló funkcionális diverzitás elemzések (GARLAND \& MILLS, 1991; ZAK et al., 1994) egy új megközelítést jelentenek a genetikai alapon történő diverzitás elemzés mellett. A módszer alapvetően különböző szénforrások mikrobiális hasznosításán alapul, amelyet eredetileg gyors mikrobiális azonosítására dolgoztak ki, azonban itt nem egyetlen izolátum, hanem a teljes mikroba-együttes aktivitását határozzák meg. Az észlelés a dehidrogenáz-enzim aktivitásán alapul, amelyet mikrotiter lemezen mikrotiter olvasó fotométerrel határoznak meg. DEGENS és HARRIS (1997) a talaj mikrobiális közösség funkcionális diverzitásának in situ jellemzésére lényegében a szubsztrát indukált respirációs módszer WEST és SPARLING (1986) által kidolgozott változatának többszubsztrátos változatát alkalmazta. A többszubsztrátos respirációs módszer mikrotiter-lemez alapú technikájával CAMPBELL et al. (2003) rendkívül hatékonnyá tette az eljárást, melynek során a talajból szubsztrát hozzáadása után képződött $\mathrm{CO}_{2}$ a detektor lemezek agaros közegében elnyelődik, majd a krezolvörös $\mathrm{pH}$ indikátor színváltozása mikrotiter fotométerrel egyszerủen leolvasható . LALOR et al. (2007) összehasonlítva DEGENS és HARRIS (1997) módszerét a mikrorespirációs módszerrel (CAMPBELL et al. 2003), megállapították, hogy különböző kezelésủ erdőtalajok jobban elkülönültek az utóbbi módszer alkalmazásával.

Az arbuszkuláris mikorrhiza (AM) gombák a legősibb és legelterjedtebb mikorrhiza típus képviselői (BRUNDRETT et al. 2009). A növényekkel kölcsönösen előnyös (mutualista) együttélésük kulcsfontosságú a gazdanövények tápanyagellátásában,

Postai cím: SzILI-KovÁcs TiBOR, MTA Talajtani és Agrokémiai Kutatóintézet, 1022 Budapest, Herman Ottó út 15.

E-mail: szili-kovacs.tibor@agrar.mta.hu 
abiotikus és biotikus stresszel szemben tanusított ellenállóképességük és a növényközösségek összetétele szempontjából (SMITH \& SMITH 2011, VAN DER HEIJDEN 1998). A szimbionták jelenléte, fertőzőképességük mértéke jó indikátora lehet a vegetáció, illetve az ökoszisztéma stabilitásának, egészségi állapotának. A szikes területeket jellemző extrém környezeti feltételek (szélsőséges vízháztartás, magas $\mathrm{pH}$ és ozmotikus stressz) mellett a növény-mikróba partnerek egymásrautaltsága nagy jelentőséggel bír. Szikes élőhelyeken az AM gombák abundanciája helyenként átlagon felüli (HILDEBRANDT et al. 2001; LANDWEHR et al. 2002). A hazai szikes talajok AM gombaközösségeinek összetételéről és müködéséről elenyésző ismerettel rendelkezünk. A gazdanövények kolonizáltsági állapotát elsősorban azok genetikailag determinált mikorrhizafüggése határozza meg, melyet számos környezeti tényező mellett a talajok felvehető foszfortartalma jelentősen befolyásol (AZCON \& OCAMPO 1981). A szikes talajok lúgos kémhatása a foszfor felvehetőségét gátolja, ami a növény igényeinek kielégítését támogató mikorrhizáció számára lehet kedvezö. FüZY és munkatársai (2008) hazai alkalikus szikeseken kimutatták, hogy az állandó vízborítottság az endomikorrhiza kolonizációt jelentősen visszaszorítja. A talaj sótartalmát leíró mennyiségek (EC, kation tartalom, $\mathrm{Na}^{+}$koncentráció, T-érték) szoros összefüggést mutattak a gyökerek arbuszkulum gazdagságának alakulásával. Az arbuszkulumok gombanövény szimbiotikus kapcsolat müködésére utaló kolonizációs paraméterek, a partnerek közti anyagcsere színhelyei (,szimbiotikus interface”).

Vizsgálatunk célkitűzése három jellegzetes alföldi szikes tó melletti eltérő toposzekvencia mentén a rizoszféra talaj mikroba-együttes katabolikus aktivitás mintázatának összehasonlító elemzése, továbbá a kiválasztott domináns növényfajok arbuszkuláris mikorrhiza gombák általi gyökér kolonizációjának elemzése volt.

\section{Anyag és módszer}

\section{Mintavétel és mintaelökészítés}

A kutatás során a Kiskunsági Nemzeti Park Felső-Kiskunsági szikes tavak területéről vettünk rizoszféra talaj és tavi üledék mintát (1. táblázat) a Böddi-szék, a Kelemen-szék és a Zab-szék mellől 2013. szeptemberében. A mintavételi helyeket BÖLÖNI és munkatársai. (2011) szerint tipizáltuk: ennek során a szikes tavak szegélyétől kiindulva az emelkedő térszínek felé zsiókás, sziki mézpázsitos és sziki legelő - ez utóbbi csak Zab-széknél - fordult elő. A „sziki legelő” eredetileg talán cickóros puszta lehetett, de a bivalyok legeltetése miatt erősen degradálódott. 


\section{1. táblázat}

A talajminták mintavételi helyei

\begin{tabular}{|c|c|c|c|}
\hline $\begin{array}{c}\text { (1) } \\
\text { Minta }\end{array}$ & $\begin{array}{l}(2) \\
\text { Minta } \\
\text { jel }\end{array}$ & $\begin{array}{c}(3) \\
\text { Koordináta (WGS84) }\end{array}$ & $\begin{array}{l}\text { (4) } \\
\text { Minta-típus, növény }\end{array}$ \\
\hline Böddi-szék (B) & $\begin{array}{l}\text { B15 } \\
\text { B16 } \\
\text { B17 }\end{array}$ & $\begin{array}{l}\text { N46,76717905; E19,15571754 } \\
\text { N46,76766522; E19,15531265 } \\
\text { N46,76837581; E19,15540571 }\end{array}$ & $\begin{array}{l}\text { (a) Mederüledék } \\
\text { (b) Zsióka } \\
\text { (c) Mézpázsit }\end{array}$ \\
\hline Kelemen-szék(K) & $\begin{array}{l}\text { K18 } \\
\text { K19 } \\
\text { K20 } \\
\text { K21 }\end{array}$ & $\begin{array}{l}\text { N46,79449751; E19,17534153 } \\
\text { N46,79340185; E19,17367544 } \\
\text { N46,79335700; E19,17355745 } \\
\text { N46,79361867; E19,17283764 }\end{array}$ & $\begin{array}{l}\text { (a) Mederüledék } \\
\text { (b) Zsióka } \\
\text { (b) Zsióka } \\
\text { (c/d) Mézpázsit/Sziki } \\
\text { őszirózsa }\end{array}$ \\
\hline Zab-szék (Z) & $\begin{array}{l}\text { Z22 } \\
\text { Z23 } \\
\text { Z24 } \\
\text { Z25 }\end{array}$ & $\begin{array}{l}\text { N46,83652901; E19,17296328 } \\
\text { N46,83626816; E19,17293646 } \\
\text { N46,83658043; E19,17528369 } \\
\text { N46,83649713; E19,17736782 }\end{array}$ & $\begin{array}{l}\text { (a) Mederüledék } \\
\text { (b) Zsióka } \\
\text { (c) Mézpázsit } \\
\text { (e) Sziki legelő }\end{array}$ \\
\hline
\end{tabular}

A minták egy részét kiszárítottuk, dörzsmozsárban homogenizálás után leszitáltuk $(<2 \mathrm{~mm})$ a fizikai és kémiai vizsgálatok céljaira, másik részét hütőszekrénybe helyeztük $\left(4{ }^{\circ} \mathrm{C}\right)$ a talajrespirációs vizsgálatokhoz. A kiszárított szitált mintákból a humusztartalom, $\mathrm{pH}_{\mathrm{H} 2 \mathrm{O}}$ (1:2,5 szuszpenzió), mésztartalom és az összes só-tartalom értékeket- a vízzel telített paszta elektromos vezetőképessége alapján - az ATK TAKI Agrokémiai laboratóriumában, a szemcseösszetételt pedig Talajfizikai laboratóriumában határozták meg, BUZÁs (1988, 1993) alapján (2. táblázat).

\section{2. táblázat}

A vizsgált talajok fontosabb fizikai és kémiai tulajdonságai

\begin{tabular}{|c|c|c|c|c|c|c|c|c|}
\hline $\begin{array}{c}(1) \\
\text { Minta } \\
\text { jel }\end{array}$ & $\begin{array}{c}(2) \\
\text { Homok } \\
2-0,05\end{array}$ & $\begin{array}{c}(3) \\
\text { Iszap } \\
0,05-0,002 \\
\mathrm{~mm}(\%)\end{array}$ & $\begin{array}{c}(4) \\
\text { Agyag } \\
<0,002 \\
\mathrm{~mm}(\%)\end{array}$ & $\begin{array}{c}(5) \\
\mathrm{H}\end{array}$ & $\begin{array}{c}\mathrm{pH} \\
\left(\mathrm{H}_{2} \mathrm{O}\right)\end{array}$ & $\begin{array}{c}\mathrm{CaCO}_{3} \\
\%\end{array}$ & $\begin{array}{c}\mathrm{EC} \\
\mu \mathrm{S} / \mathrm{cm}\end{array}$ & $\begin{array}{c}\mathrm{pF}=0 \\
\mathrm{~m} / \mathrm{m} \\
\%\end{array}$ \\
\hline $\mathrm{B} 15$ & 29,13 & 52,30 & 18,57 & 0,842 & 10,1 & 29,7 & 3570 & 32,2 \\
$\mathrm{~B} 16$ & 20,92 & 58,29 & 20,79 & 0,947 & 10,0 & 31,1 & 2730 & 27,0 \\
$\mathrm{~B} 17$ & 19,44 & 63,67 & 16,89 & 0,683 & 10,2 & 27,4 & 4280 & 31,0 \\
$\mathrm{~K} 18$ & 14,03 & 61,64 & 24,33 & 0,747 & 10,3 & 29,5 & 5780 & 37,6 \\
$\mathrm{~K} 19$ & 14,35 & 58,74 & 26,91 & 2,89 & 8,98 & 30,3 & 2880 & 35,4 \\
$\mathrm{~K} 20$ & 25,92 & 48,29 & 25,80 & 1,48 & 9,49 & 27,9 & 2720 & 24,6 \\
$\mathrm{~K} 21$ & 18,36 & 63,38 & 18,26 & 2,21 & 9,77 & 13,9 & 2860 & 38,4 \\
$\mathrm{Z} 22$ & 67,57 & 18,87 & 13,56 & 0,325 & 10,3 & 14,6 & 2560 & 22,3 \\
Z23 & 61,14 & 18,66 & 20,21 & 0,394 & 10,0 & 16,2 & 947 & 27,8 \\
Z24 & 51,10 & 44,65 & 4,25 & 1,12 & 9,13 & 20,8 & 355 & 28,7 \\
Z25 & 34,95 & 50,24 & 14,82 & 3,48 & 7,82 & 21,3 & 271 & 43,9 \\
\hline
\end{tabular}


A talajminták nedvességét a szabadföldi vízkapacitás közeli értékre állítottuk, ehhez levegőn történő szárításra volt szükség, mivel a minták nedvességtartalma meghaladta ezt az értéket. Ezt követően $2 \mathrm{~mm}$-es szitán átengedtük, és egyhetes előinkubációt alkalmaztunk a mérések előtt, ekszikkátorban víz és szódamész jelenlétében. A talajmintavétel mellett növénymintát is vettünk mind a 3 területen, a bennszülött arbuszkuláris mikorrhiza gombák (AM gombák) jelenlétének, illetve gyökér-kolonizációjának kimutatására. A növénymintavétel a talajmintavételek közelében történt. Mindhárom élőhelyen előforduló, mikorrhizát képező erősen mikorrhizafüggő sziki őszirózsa(Tripolium pannonicum $=$ Aster) és a kevésbé mikorrhizafüggő sziki mézpázsit (Puccinellia limosa) kolonizációs állapotát vizsgáltuk.

\section{Alap- és szubsztrát-indukált respiráció}

$\mathrm{Az}$ alaprespiráció méréshez 2,0 g talajt mértünk be $25 \mathrm{~cm}^{3}$ üvegedényekbe, melyeket butilgumi-szeptummal zártunk le. Az edényben képződött $\mathrm{CO}_{2}$-t 4 és 24 óra elteltével mértük, a két mérés különbségéből számítottuk ki a $\mathrm{CO}_{2}$ képződés sebességét. A szubsztrát-indukált respiráció mérése ugyancsak $25 \mathrm{~cm}^{3}$ edényekbe mért 2,0 g talajmintákkal történt (SZILI-KOVÁCS \& TÖRÖK 2005). A mintákhoz 200 $\mu$ szubsztrát oldatot adtunk, az oldat hozzáadása után 20 perccel zártuk le az edényeket, a képződött $\mathrm{CO}_{2}$-t 3 és 5 óra inkubáció után mértük. Az inkubáció az alap- és szubsztrát-indukált respiráció mérésénél is rázó-vízfürdőben volt $\left(25^{\circ} \mathrm{C} \pm\right.$ $0.1^{\circ} \mathrm{C}, 60$ fordulat/perc), minden mintát 4 ismétlésben mértünk. A laborlevegő $\mathrm{CO}_{2}$ koncentrációját is megmértük, ezt vettük figyelembe a kiindulási $\mathrm{CO}_{2}$ koncentrációnak a szubsztrát-indukált respiráció meghatározása során. A következő szubsztrátokat alkalmaztuk: D-glükóz, D-fruktóz, L-arabinóz, trehalóz $80 \mathrm{~g} \mathrm{l}^{-1}$, dinátrium-szukcinát $40 \mathrm{~g} \mathrm{l}^{-1}$. A CO 2 mérését gázkromatográffal (FISONS GC8000, Milano, Italy) végeztük, $250 \mu 1$ gázmintából.

\section{Katabolikus aktivitás-mintázat mérése mikrorespirációval}

A Microresp ${ }^{\mathrm{TM}}$ módszert alkalmaztuk a talaj mikrobiális közösség katabolikus aktivitás-mintázatának vizsgálatára (CAMPBELL et al. 2003). A mikrorespirációs rendszer a szubsztrát talajmintához történő hozzáadása után képződött széndioxid kolorimetrikus detektálásán alapul. A mérés során két 96-kamrás mikrotiter lemez van egymással szembe helyezve, az ún. "deepwell-plate" (DWP) 1,2 ml térfogatú kamráiban található a talaj a hozzáadott szubsztrátokkal, a másik vele szemben elhelyezett mikrotiter lemez tartalmazza a krezolvörös indikátort agargélben (Oxoid agar). A két szembe helyezett lemezt teflonbevonatú szilikonlapka (MicroResp ${ }^{\mathrm{TM}}$ Seal) tömítés köti össze, az egymással szemben elhelyezkedö kamrák a tömítésben lévő lyukak révén szabadon átjárhatók.

A talajmintákat szobahőmérsékleten inkubáltuk, amíg a víztartó képességük 50\%-körüli értékét elérték, majd parafilmmel lezártuk és exszikkátorba helyeztük, amiben egy-egy fözőpohárban víz illetve szódamész volt. Öt nap inkubáció után a 
talajmintákat betöltöttük a DWP-kbe a betöltő eszközzel (MicroResp ${ }^{\mathrm{TM}}$ Filling Device) közel azonos talajtérfogatra $(300 \mu \mathrm{l})$ mind a 96 kamrába.

A DWP egy kamrájába betöltött átlagos talaj száraztömeget a talajjal töltött 96kamrás DWP tömegéből az üres DWP tömegének kivonása után számítottuk ki, figyelembe véve a talaj nedvességtartalmát. A DWP-eket ezután parafilmmel lezártuk.

A következő nap $25 \mu \mathrm{l}$ szubsztrát-oldatot adagolunk a talajokat tartalmazó DWP-hez 8-csatornás pipettorral. 15 különböző szénforrás-oldatot és desztillált vizet adagoltunk 6 ismétlésben: D-galaktóz, trehalóz, L-arabinóz, D-glükóz és Dfruktóz $80 \mathrm{mg} \mathrm{ml}^{-1}$, citromsav, DL-almasav, Na-szukcinát, L-alanin, és L-lizin 40 $\mathrm{mg} \mathrm{ml}^{-1}$, L-glutamin $20 \mathrm{mg} \mathrm{ml}^{-1}$, L-leucin, L-arginin, 3,4-dihidroxibenzoesav és Lglutaminsav $12 \mathrm{mg} \mathrm{ml}^{-1}$. A szubsztrát oldatok $\mathrm{pH}$-ját 5,5-6,0 közé állítottuk be $1 \mathrm{M}$ $\mathrm{NaOH}$ vagy $\mathrm{HCl}$ oldat hozzáadásával. A szubsztrát hozzáadás után 30 perccel zártuk le a lemezeket, azért, hogy az abiotikus $\mathrm{CO}_{2}$ eltávozhasson. A lezárás eredeti lezáróval (MicroResp ${ }^{\mathrm{TM}}$ Clamp) és saját készítésủ fémlezáróval történt. A lezárt lemezeket $25{ }^{\circ} \mathrm{C}$-os termosztátba helyeztük és 5 órán keresztül inkubáltuk. A detektor lemezeket közvetlenül a szubsztrát adagolása előtt, valamint a lemezek 5 órás inkubációja után mértïk fotométerrel (Anthos 2010, Biochrom, Cambridge, UK), $570 \mathrm{~nm}$ szürővel. A fotométer számítógéphez kapcsolva az ADAP programmal müködött. Az egy lemezröl leolvasott abszorbancia értékeket átmásoltuk MS Excel programba további adatfeldolgozáshoz. Az 5 óra inkubáció után kapott abszorbancia értékeket a $\mathrm{t}=0$ időpontban mért abszorbancia értékekkel normalizáltuk, majd átszámítottuk $\mathrm{CO}_{2}$ térfogatszázalékra, majd $\mathrm{CO}_{2}$ koncentrációra a következő kalibrációs görbe alapján: $\% \mathrm{CO}_{2}=\mathrm{A}+\mathrm{B} /\left(1+\mathrm{Dx} \mathrm{A}_{\mathrm{i}}\right) ; \mathrm{A}_{\mathrm{i}}$ az átlagos abszorbancia érték egy meghatározott $\mathrm{CO}_{2}$ koncentrációnál, és $\mathrm{A}, \mathrm{B}$ és $\mathrm{D}$ a modellparaméterek. A respiráció sebességét a normalizált térfogatszázalékos $\mathrm{CO}_{2}$ adatokból számítottuk. Minden lemezt egyedileg kalibráltunk, úgy hogy exszikkátorba helyeztük őket és eltérő $\mathrm{CO}_{2}$ koncentráció mellett mértük az exszikkátorban lévő $\mathrm{CO}_{2}$ koncentrációt majd a lemezek abszorbancia értékeit a fotométerrel.

\section{Gyökérkolonizációs vizsgálatok}

Az AM gombák gyökérkolonizációs vizsgálata a gyökerek anilinkékkel történő festését követően (PHILLIPS \& HAYMAN 1970) Olympus BX51 (Olympus Corp., Tokyo, Japan) típusú fénymikroszkóppal történt (40-200X). TROUVELOT és munkatársai (1986) módszere alapján meghatároztuk az AM gombák gyökérkolonizációs mutatóit, az infekció intenzitását (M \%) és az arbuszkulumgazdagságot (A\%) (FÜZY et al. 2015).

\section{Statisztikai értékelések}

Egytényezős variancia-analízist használtunk az adatok értékelése során. A katabolikus aktivitás (szubsztrát-indukált respiráció) adatokat a szubsztrát átlagokra normalizáltuk és a többváltozós statisztikai eljárások közül a főkoordináta elemzést 
(PCoA) választottuk "Bray-Curtis" távolság függvénnyel az R-Vegan programcsomag segítségével, kiegészítve a környezeti változókkal való kapcsolat feltárását az envfit funkcióval (OKSANEN et al. 2014).

\section{Eredmények és megvitatásuk}

A gázkromatográfiás méréssel meghatározott alap- és szubsztrát-indukált respiráció

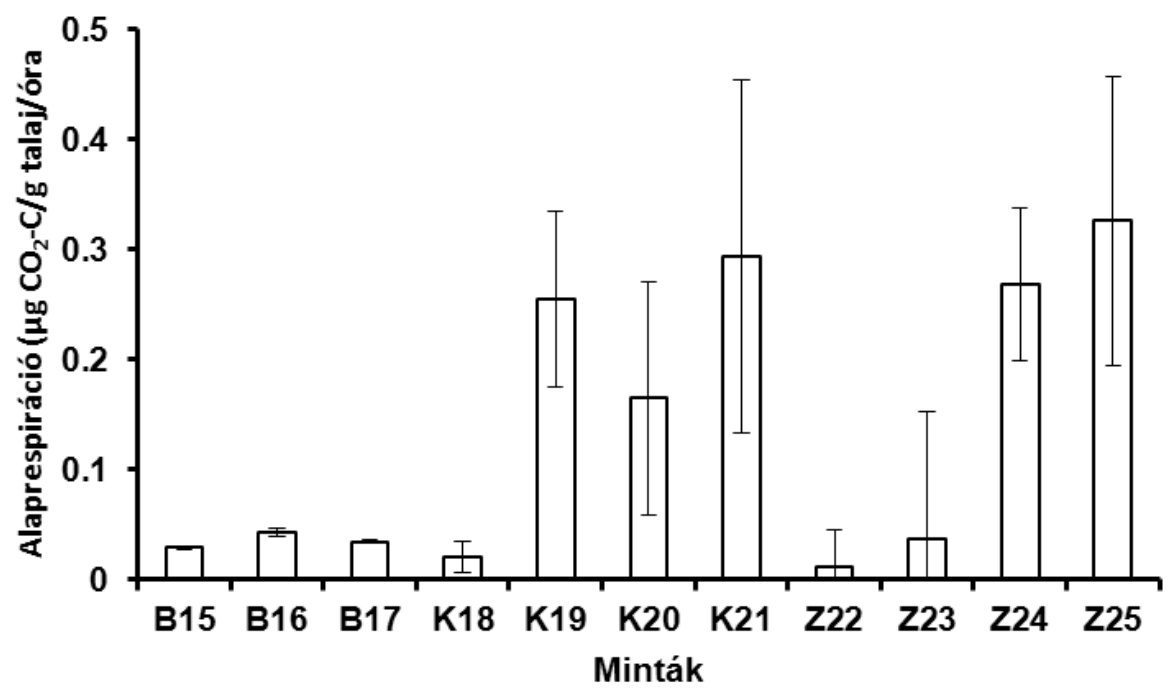

\section{1. ábra}

A vizsgált tavi üledékek (B15, K18 és Z22) és talajminták (B16-17, K19-21 és Z23-25) gázkromatográffal mért alaprespirációjának átlagai a szórások feltűntetésével

Az alaprespiráció a mederüledék mintákban volt a legkisebb (B15, K18 és Z22), ezt követték a zsiókás minták (B16, Z23) és a mézpázsitos minta a Böddi-székről (B17) (1. ábra). A Kelemen-székről gyüjtött (K19, K20 és K21) és a zab-széki (Z24 és Z25) minták alaprespirációja jóval nagyobb volt, a nagy szórás miatt azonban szignifikáns különbségeket ezek között nem tudtunk kimutatni. Az alaprespiráció a vizsgált talajparaméterek közül korrelációban volt a humusztartalommal $(\mathrm{r}=0,88$; $P=0,0003)$, a $\mathrm{pH}$-val $(\mathrm{r}=-0,84 ; P=0,0012)$ és kisebb mértékben, marginálisan a vezetőképességgel $(\mathrm{r}=0,55 ; P=0,08)$. Az alaprespiráció és a humusztartalom közötti pozitív összefüggés jól ismert, továbbá az is nyilvánvaló, hogy a pH befolyásolja a mikrobiális aktivitást. Azonban pontosan nem tudhatjuk, hogy a $\mathrm{pH}$ és az alaprespiráció közötti szoros korreláció közvetlenül a kémhatásból származik, vagy a nagyobb $\mathrm{pH}$ érték melletti alacsonyabb humusztartalomnak tulajdonítható. 


\section{3. táblázat}

A tavi üledékek (B15, K18 és Z22) és rizoszféra talajminták (B16-17, K19-21 és Z23-25) gázkromatográffal mért szubsztrát-indukált respirációjának átlagai ( $\mu \mathrm{g} \mathrm{CO}_{2}-\mathrm{C} / \mathrm{g}$ talaj/óra) a

szórások feltüntetésével; a szignifikáns különbségek $(P<0,05)$ eltérő betükkel jelölve a szórások után

\begin{tabular}{|c|c|c|c|c|c|}
\hline $\begin{array}{c}\text { (1) } \\
\text { Minta jel }\end{array}$ & $\begin{array}{c}(2) \\
\text { Glükóz }\end{array}$ & $\begin{array}{c}\text { (3) } \\
\text { Szukcinát }\end{array}$ & $\begin{array}{c}\text { (4) } \\
\text { Arabinóz }\end{array}$ & $\begin{array}{c}(5) \\
\text { Trehalóz }\end{array}$ & $\begin{array}{c}(6) \\
\text { Fruktóz }\end{array}$ \\
\hline \multicolumn{6}{|c|}{ Böddi-szék } \\
\hline B15 & $0,144 \pm 0,05 a$ & $0,159 \pm 0,12 \mathrm{a}$ & $0,104 \pm 0,03 a$ & $0,074 \pm 0,02 \mathrm{a}$ & $0,311 \pm 0,05 \mathrm{a}$ \\
\hline B16 & $0,498 \pm 0,15 b$ & $0,193 \pm 0,07 \mathrm{a}$ & $0,308 \pm 0,20 \mathrm{a}$ & $0,311 \pm 0,07 b$ & $0,683 \pm 0,05 b$ \\
\hline B17 & $1,622 \pm 0,49 \mathrm{c}$ & $0,290 \pm 0,17 \mathrm{a}$ & $1,774 \pm 0,80 \mathrm{~b}$ & $0,293 \pm 0,08 b$ & $0,520 \pm 0,00 \mathrm{c}$ \\
\hline \multicolumn{6}{|c|}{ Kelemen-szék } \\
\hline K18 & $0,248 \pm 0,06 a$ & $0,207 \pm 0,11 \mathrm{a}$ & $0,191 \pm 0,13 a$ & $0,066 \pm 0,04 a$ & $0,434 \pm 0,03 \mathrm{a}$ \\
\hline K19 & $5,907 \pm 0,93 b$ & $3,815 \pm 0,98 b$ & $5,094 \pm 0,69 b$ & $3,976 \pm 0,24 b$ & $3,537 \pm 0,27 b$ \\
\hline $\mathrm{K} 20$ & $4,489 \pm 0,09 c$ & $1,895 \pm 0,47 \mathrm{c}$ & $1,600 \pm 1,05 \mathrm{a}$ & $1,767 \pm 0,39 \mathrm{c}$ & $2,538 \pm 1,15 b$ \\
\hline K21 & $9,566 \pm 0,49 d$ & $4,377 \pm 0,78 d$ & $8,028 \pm 2,08 \mathrm{c}$ & $2,888 \pm 0,44 d$ & $2,192 \pm 0,35 b$ \\
\hline \multicolumn{6}{|c|}{ Zab-szék } \\
\hline $\mathrm{Z} 22$ & $0,118 \pm 0,10 \mathrm{a}$ & $0,122 \pm 0,01 \mathrm{a}$ & $0,122 \pm 0,05 \mathrm{a}$ & $0,080 \pm 0,02 \mathrm{a}$ & $0,287 \pm 0,07 \mathrm{a}$ \\
\hline $\mathrm{Z} 23$ & $0,787 \pm 0,41 b$ & $0,838 \pm 0,20 b$ & $0,425 \pm 0,10 b$ & $0,371 \pm 0,14 a$ & $1,094 \pm 0,17 b$ \\
\hline Z24 & $5,916 \pm 0,66 \mathrm{c}$ & $4,065 \pm 0,29 \mathrm{c}$ & $4,021 \pm 0,32 c$ & $3,327 \pm 0,28 b$ & $2,853 \pm 0,18 \mathrm{c}$ \\
\hline $\mathrm{Z} 25$ & $11,65 \pm 1,32 \mathrm{~d}$ & $7,373 \pm 0,71 \mathrm{~d}$ & $6,453 \pm 0,81 d$ & $5,170 \pm 0,29 \mathrm{c}$ & $8,668 \pm 0,76 \mathrm{~d}$ \\
\hline
\end{tabular}

A szubsztrát-indukált respirációt (SIR) 5 eltérő szubsztrát hozzáadása után mértük, gyakorlatilag egy nap csak egy szubsztrátot, mivel a 11 mintát 4 ismétlésben mértük, és nagyjából ez az egy nap alatt mérhető adag. A Böddi-szék mintáiban volt a legalacsonyabb az aktivitás. Glükóz hozzáadására mind a három helyen a minták között a SIR szignifikáns volt (3. táblázat). Szukcinát hozzáadása után mért SIR a kelemen-széki és zab-széki minták esetében egyaránt szignifikáns volt, míg a böddi-széki talajoknál nem volt eltérés. Arabinóz hozzáadása után minden zab-széki talaj között a SIR szignifikánsan különbözött, a böddi-széki és kelemen-széki talajoknál viszont nem. Trehalóz hozzáadása után minden kelemenszéki talaj SIR szignifikánsan különbözött, a zab-széki és böddi-széki talajoknál nem. Végül fruktóz hozzáadása után minden böddi-széki és zab-széki talaj SIR szignifikánsan különbözött, a kelemen-székiek viszont nem (3. táblázat). A különböző szubsztrátok tehát helyenként eltérő mértékben különítik el a talajokat, eltérő szubsztrát-hasznosítási mintázatot eredményezve. Egy további megfigyelést kell megemlítenünk a SIR méréssel kapcsolatban. A szubsztrát talajhoz történő hozzáadása után több esetben - elsősorban a mederüledék és a zsiókás mintáknál a talaj fölötti levegő $\mathrm{CO}_{2}$ koncentrációja lecsökkent, vagyis a talaj $\mathrm{CO}_{2}$-t nyelt el, és a szubsztrát hasznosításból származó $\mathrm{CO}_{2}$ növekmény csak hosszabb inkubációs idő után jelent meg. Ezt a jelenséget már ANDERSON és DOMSCH (1978) is leírta néhány nagy szervesanyag tartalmú talajnál. Ez az oka annak, amiért a módszertani 
részben leírtak szerint nem a 0 és 3 óra közötti, hanem a 3 és 5 óra inkubációs idő közötti $\mathrm{CO}_{2}$ képződésből számítottuk ki a respiráció sebességét.

\section{Szubsztrát-indukált respiráció mikrorespirációs (MicorResp ${ }^{T M}$ ) módszerrel}

Összehasonlításként a 11 minta közül 7 mintából végeztük el a mikrorespirációs mérést, kihagyva a mederüledék mintákat, melyeknek amúgy is nagyon alacsony a respirációs aktivitása, így nehezen értékelhetők, továbbá a kelemen-széki K20-as mintát, mivel a K19-hez hasonlóan az is zsiókás volt. Mikrorespirációs méréseket a gázkromatográffal mért SIR értékekkel együtt ábrázoltuk (2. ábra), az összehasonlítás kedvéért. Az rögtön szembetűnik, hogy a gázkromatográfiás méréssel kapott értékek jóval nagyobbak a mikrorespirációval kapott adatoknál. A két különböző módszerrel mért szubsztrát indukált respiráció között szignifikáns korreláció $(\mathrm{r}=0,82 ; p<0,0001)$ a K21-es minta kihagyásával még erősebb ( $\mathrm{r}=0,93$; $\mathrm{p}<0,0001)$. Ugyanakkor szubsztrátonként összehasonlítva az arabinóz esetében nem volt szignifikáns korreláció a két mérési módszer között $(\mathrm{r}=0,58 ; p=0,17)$, a többi szubsztrát esetében viszont igen.
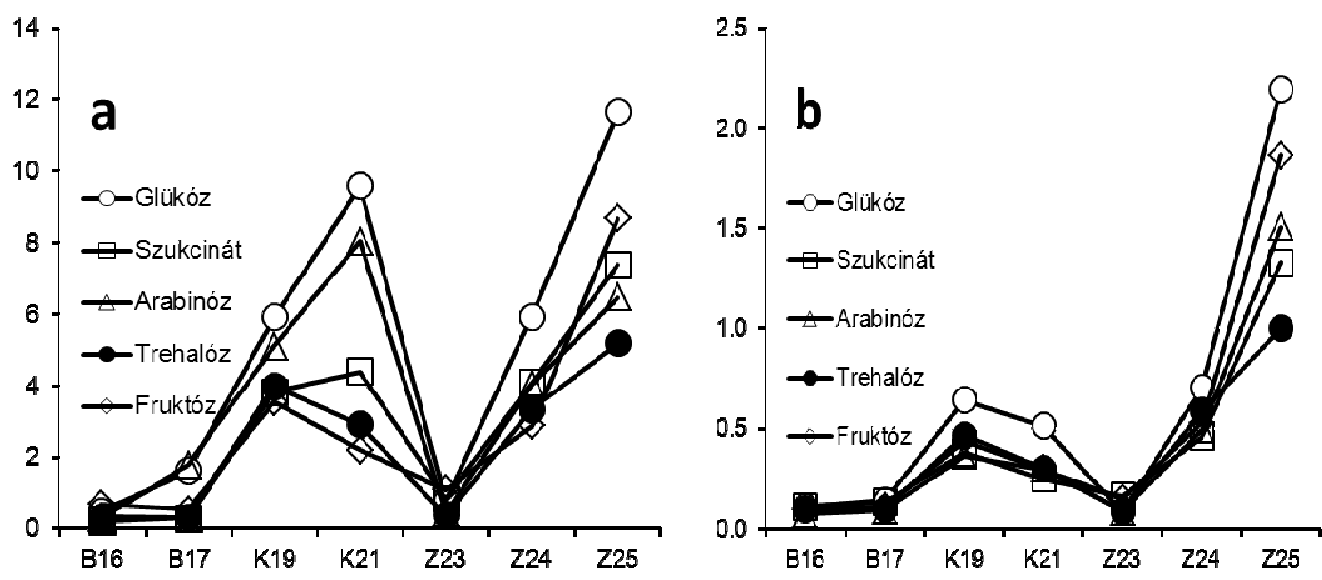

2. ábra

A szubsztrát-indukált respiráció méréseinek összehasonlítása gázkromatográffal (a) illetve mikrorespirációs módszerrel (b) mérve ( $\mu \mathrm{g} \mathrm{CO}_{2}-\mathrm{C} / \mathrm{g}$ talaj/óra)

LALOR és munkatársai (2007) átlagosan hatszor nagyobb respirációs értéket kaptak a DEGENS \& HARRIS (1997) módszerrel, mint a mikrorespirációs méréssel. Ennek valószínủleg az lehet az oka, hogy a gázkromatográfiás mérésnél az edény levegötérfogata sokkal nagyobb, tehát több oxigén áll rendelkezésre a légzéshez. Ugyanakkor a szubsztrátokra adott válasz a két módszerrel hasonló tendenciát mutatott, talán a K21 minta esetében volt jelentősebb eltérés a két módszer között. 


\section{Szubsztrát-hasznosítási mintázat és a környezeti változók}

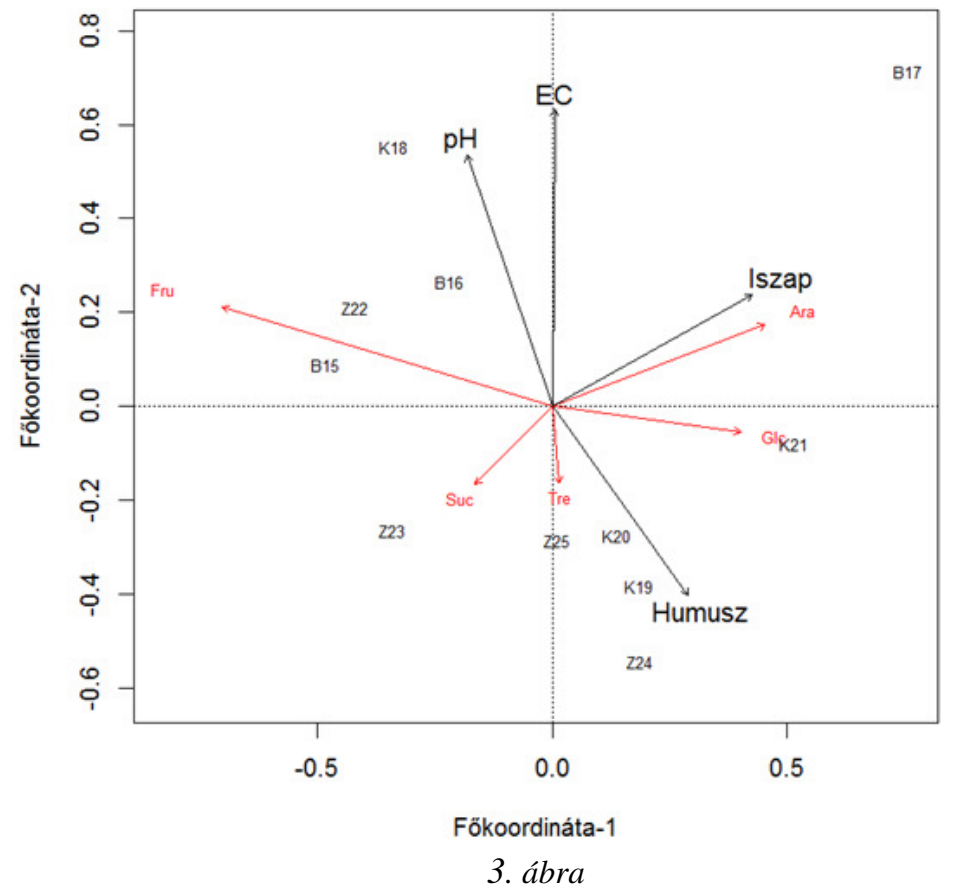

Főkoordináta elemzés a gázkromatográffal mért SIR értékeiből (5 szubsztrát) és négy

környezeti változó (humusztartalom, pH, vezetőképesség (EC), iszap-tartalom (\%)

felhasználásával a vizsgált 11 mintánál (az 1. főkoordináta az összvariancia 76\%-át a 2. főkoordináta $11 \%$-a magyarázza)

A katabolikus aktivitás-mintázat és a környezeti változók közötti összefüggések feltárására főkoordináta elemzést és a környezeti változókkal való regresszióanalízist végeztünk. A gázkromatográffal meghatározott SIR (3. ábra) és a mikrorespirációval mért SIR (4. ábra) ordinációját négy környezeti változóval ábrázoltunk, mivel az itt nem említett egyéb elemzések során ezeknek kimutatható hatásuk volt. A mederüledék minták szorosan egymás mellett helyezkednek el, mivel ezeknél a környezeti feltételek élesen elkülönülnek a talajokétól. A mikrorespirációs méréssel merőben eltérően helyezkednek el e minták egymáshoz képest, aminek egyrészt az az oka, hogy itt csak 7 minta szerepel a 11-ből, másrészt viszont 15 szubsztrát respirációs mintázata szerepel szemben az 5-szubsztrátos gázkromatográfiás méréssel. Ugyanakkor a 3. ábrán bemutatott összehasonlítás szerint néhány esetben az azonos szubsztrátok is némileg eltérő tendenciájú eredményt adnak. Mind a két elemzés azt mutatja, hogy a humusztartalom és a pH változása egymással ellentétes módon hat, a sótartalom inkább a pH-val mutat szorosabb kapcsolatot, az iszaptartalom pedig látszólag független tỏlük, hiszen közel merőlegesen helyezkedik el hozzájuk képest. A környezeti változók illesztése során a gázkromatográfiás mérésnél a $\mathrm{pH}$ és a vezetőképesség, míg a 
mikrorespirációs mérésnél a pH és a humusztartalom hatása volt szignifikáns (4. táblázat). WAKELIN és munkatársai. (2008) különböző mezőgazdasági művelésű talajokon kimutatták, hogy a talaj $\mathrm{pH}$ a legfontosabb szelekciós faktor mind a genetikai, mind a katabolikus aktivitás mintázat tekintetében, továbbá azt is, hogy a mikrorespirációval meghatározott katabolikus aktivitás-mintázat sokkal szorosabb összefüggésben van a bakteriális- , mint a gomba közösség-szerkezettel.

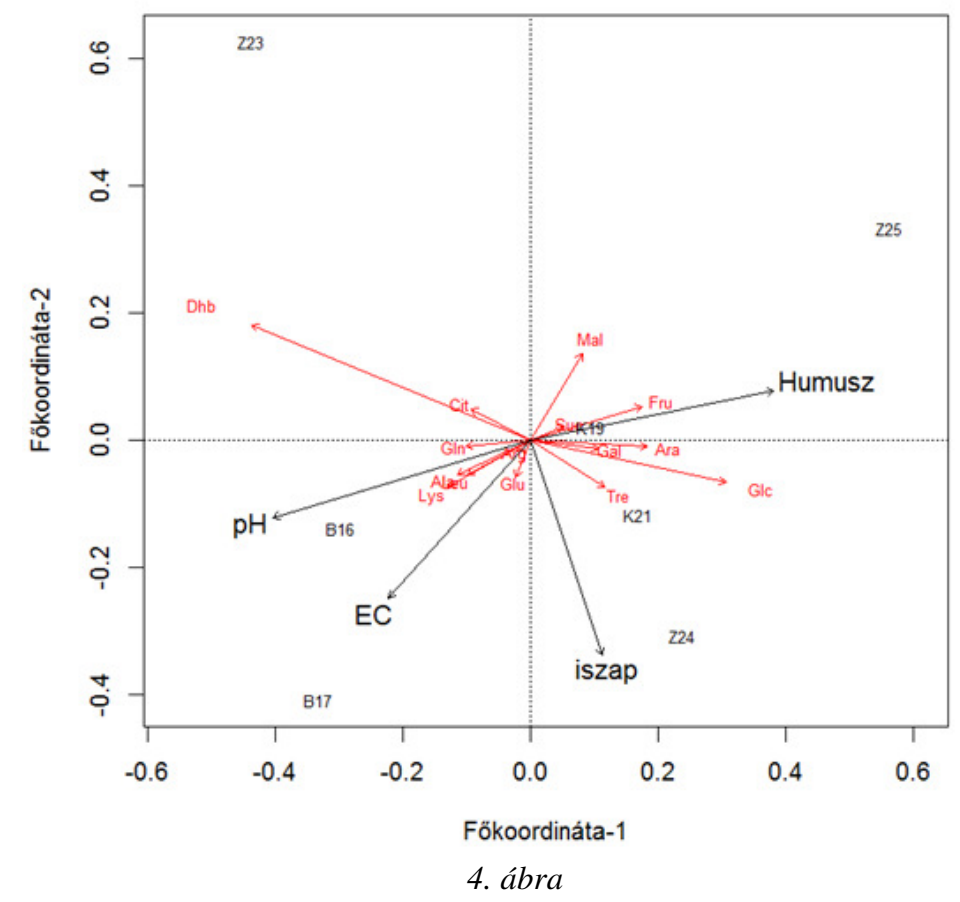

Főkoordináta elemzés a mikrorespirációs adatok szubsztrát-átlagra normalizált értékeiből (15 szubsztrát) és négy környezeti változó (humusztartalom, pH, vezetőképesség (EC) és iszaptartalom (\%) felhasználásával a vizsgált 7 mintánál (az 1. fökoordináta az összvariancia $77 \%$-át a 2. fökoordináta $14 \%$-a magyarázza)

\section{4. táblázat}

Környezeti változók vektorként történő illesztése az ordinációs diagramokra (Vegan - envfit funkcióval; 999 permutáció), korreláció és szignifikancia feltűntetésével.

\begin{tabular}{|l|l|l|l|l|}
\hline & \multicolumn{2}{|l|}{ gázkromatográfiás SIR mérés } & \multicolumn{2}{l|}{ mikrorespiráció } \\
& $\mathrm{r}^{2}$ & $\mathrm{P}>\mathrm{r}$ & $\mathrm{r}^{2}$ & $\mathrm{P}>\mathrm{r}$ \\
\hline $\mathrm{pH}$ & 0,497 & $\mathbf{0 , 0 6 +}$ & 0,818 & $\mathbf{0 , 0 3 2} *$ \\
$\mathrm{EC}(\mu \mathrm{S} / \mathrm{cm})$ & 0,622 & $\mathbf{0 , 0 1 3}$ & 0,695 & 0,106 \\
Humusz $(\%)$ & 0,381 & 0,153 & 0,731 & $\mathbf{0 , 0 9 6 +}$ \\
Homok $(\%)$ & 0,273 & 0,265 & 0,592 & 0,209 \\
Iszap $(\%)$ & 0,368 & 0,165 & 0,6826 & 0,101 \\
Agyag $(\%)$ & 0,044 & 0,845 & 0,1873 & 0,683 \\
\hline
\end{tabular}


AM gomba gyökérkolonizáció

A két vizsgált növényfaj (sziki őszirózsa - Tripolium pannonicum és sziki mézpázsit - Puccinellia limosa) és a három mintavételi helyszín között a gyökérkolonizációban jelentős különbségek mutathatók ki (5. ábra). Magasabb kolonizációs értékek tartoznak a mikorrhizafüggő sziki őszirózsa gyökérmintáihoz, mint a kevésbé mikorrhizafüggő sziki mézpázsithoz. Jelentős a kolonizáció Kelemen-szék mintaterületen, míg Böddi-széken a mikorrhizafüggő őszirózsa gyökereiben is csak nyomokban találtunk kolonizációt.

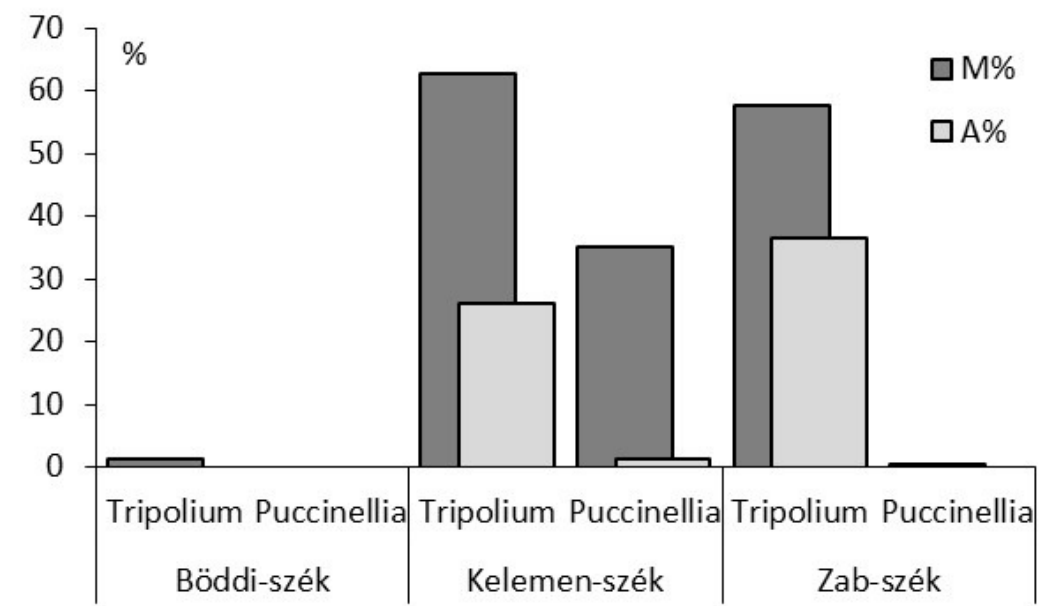

5. ábra

A vizsgált növények (Tripolium pannonicum = Aster és Puccinellia limosa) gyökérkolonizációs értékei a három mintavételi helyszínen (M\%: a kolonizáció intenzitása; A\%: az arbuszkulum gazdagság mértéke)

A vizsgált talaj-paraméterek a három helyszínen nem indokolják a jelentős különbségeket az AM gombák kolonizációban, okait talán az időszakos vízjárásban, vízborításban, kiszáradásban lehet keresni, ami rendszeres monitorozást igényel. A tartós vízborítás és hipoxiás környezet csökkenti az AM gomba kolonizációt (HATTORI et al. 2013). A sziki őszirózsa magas kolonizáltsága magyarázható aerenchima-képző tulajdonságaival, mely lehetővé teszi mind a növény mind pedig szimbionta partnere számára a vízborításos időszakok túlélését (CARVAlHo et al. 2003).

\section{Következtetések}

A mikrorespirációs (MicroResp ${ }^{\mathrm{TM}}$ ) módszerrel jellemzett katabolikus aktivitás mintázat a különböző helyről származó szikes talajminták között eltérést mutatott. A talaj humusztartalma, a pH és az elektromos vezetőképességgel jellemzett 
sótartalom összefüggést mutattak a katabolikus aktivitásban tapasztalt eltérésekkel. A sziki őszirózsa magasabb AM kolonizációt mutatott, mint a sziki mézpázsit, ugyanakkor a kolonizáció mértékének mintavételi helyek közötti eltérését nem lehetett a talajparaméterekkel magyarázni.

\section{Összefoglalás}

A szikes talajok szélsőséges vízháztartásuk, nagy sótartalmuk és alkalikus kémhatásuk miatt az élőlények alkalmazkodását alaposan próbára teszik. A talaj mikrobiális közösség katabolikus aktivitás mintázatát hasonlítottuk össze három szikes tó, a Böddi-szék, a Kelemen-szék és a Zab-szék (Felső-Kiskunsági szikes tavak) partközeli vegetációjának rizoszférájában az iszaptól a zsiókáson és a mézpázsiton keresztül a homoki legelöig. Feltételeztük, hogy a szikes jellegben és a növényzetben meglévő különbségek a mikrobiális közösségre is hatást gyakorolnak. Kezdeti eredményeink azt mutatták, hogy a szubsztrát hasznosítási mintázat alapján az egyes minták jól elkülönültek egymástól. Az alaprespiráció elsősorban a talaj humusztartalmával mutatott szoros összefüggést. A katabolikus aktivitás mintázatokat 5 szubsztrát alapján a gázkromatográfiás SIR méréssel a pH és EC, míg 15 szubsztrát alapján mikrorespirációval a $\mathrm{pH}$ és humusztartalom szignifikánsan befolyásolta, a növényzet közvetlen hatása kevésbé volt igazolható.

A szélsőséges talajtulajdonságokkal jellemezhető élőhelyeken, mint amilyenek a szikesek, a növények túlélésében az arbuszkuláris mikorhiza (AM) gombák fontos szerepet játszanak. Az AM gombák kolonizációjában jelentős különbség adódott két domináns növényfaj, a sziki őszirózsa és a sziki mézpázsit között, az előbbi jóval erőteljesebb kolonizációt mutatott. Ugyanazon növényfaj AM kolonizációja a három területen eltérő volt, ami nem magyarázható a talaj tulajdonságokkal.

A kutatást az OTKA (K 108572) támogatta.

Kulcsszavak: AM gombák, Microresp, talajlégzés, szubsztrát indukált respiráció

\section{Irodalom}

Anderson, J. P. E. \& Domsch, K. H., 1978. A physiological method for the quantitative measurement of microbial biomass in soils. Soil Biol. Biochem. 10. 215-221.

AZCON, R. \& OCAMPO, J.A. 1981. Factors affecting the vesicular arbuscular infection and mycorrhizal dependency of thirteen wheat cultivars. New Phytol 87. 677-685.

BÁrÁny, Á., Szili-Kovács, T., Krett, G., Füzy, A., MÁrialigeti, K. \& Borsodi, A.K.(2014. Metabolic activity and genetic diversity of microbial communities inhabiting the rhizosphere of halophyton plants. Acta Microbiologica et Immunologica Hungarica 61. 347-361.

Borsodi, A.K., Vladár, P., Rusznyák, A., Szabó, G., Sipos, R. \& Márialigeti, K. 2005. Tenyésztésen alapuló és tenyésztéstől független molekuláris biológiai vizsgálatok a Kiskunsági NP szikes tavainak baktériumközösségein. Hidrol Közl 85. 23-25. 
Borsodi, A.K., BárÁny, Á., Krett, G., Márialigeti, K. \& Szili-Kovács, T. 2015. Diversity and ecological tolerance of bacteria isolated from the rhizosphere of halophyton plants living nearby kiskunság soda ponds, Hungary. Acta Microbiologica et Immunologica Hungarica 62. 183-197.

BÖLÖNI, J., MOLNÁR, Zs. \& KUN, A. 2011. Magyarország élőhelyei; Vegetációtípusok leírása és határozója - ÁNÉR 2011, MTA ÖBKI, Vácrátót.

BRUNDRETT, M. C. 2009. Mycorrhizal associations and other means of nutrition of vascular plants: understanding the global diversity of host plants by resolving conflicting information and developing reliable means of diagnosis. Plant and Soil 320. 37-77.

BUZÁS I. (szerk.) (1988 ): Talaj- és agrokémiai vizsgálati módszerkönyv 2. Mezőgazdasági kiadó. Budapest

BUZÁs I. (szerk.) (1993 ): Talaj- és agrokémiai vizsgálati módszerkönyv 1. INDA 4231. Budapest

Carvalho, L. M., Correia, P. M., CaAdor, I. \& Martins-LoucaO, M. A., 2003. Effects of salinity and flooding on the infectivity of salt marsh arbuscular mycorrhizal fungi in Aster tripolium L. Biol Fertil Soils 38. 137-143.

Campbell, C.D., Chapman, S.J., Cameron, C.M., Davidson, M.S. \& PotTs, J.M. 2003. A rapid microtiter plate method to measure carbon dioxide evolved from carbon substrate amendments so as to determine the physiological profiles of soil microbial communities by using whole soil. Appl Environ Microbiol 69. 3593-3599.

DEgENS, B. P. \& HARRIS, J. A. 1997. Development of physiological approach to measuring the catabolic diversity of soil microbial communities. Soil Biol. Biochem. 29. 13091320.

Füzy, A., Biró, B., Tóth, T., HildebrandT, U. \& Bothe, H., 2008. Drought, but not salinity, determines the apparent effectiveness of halophytes colonized by arbuscular mycorrhizal fungi. Journal of plant physiology, 165. 1181-1192.

FÜZY, A., BIRÓ, I., KovÁcs, R. \& TAKÁCS, T. 2015: Estimation of AM fungal colonization comparability and realiability of classical methods. Acta Microbiologica et Immunologica Hungarica 62. 435-452.

GaRland, J. L. \& MiLlS, A. L. 1991. Classification and characterization of heterotrophic microbial communities on the basis of patterns of community-level sole-carbon source utilization. Appl. Environ. Microbiol. 57. 2351-2359.

Hattori, R., Matsumura, A., Yamawaki, K., TARui, A. \& Daimon, H., 2013. Effects of flooding on arbuscular mycorrhizal colonization and root-nodule formation in different roots of soybeans. Agricultural Sciences 4. 673-677

Hildebrandt, U., Janetta, K., Ouziad, F., Renne, B., Nawrath, K. \& Bothe, H., 2001. Arbuscular mycorrhizal colonization of halophytes in Central European salt marshes. Mycorrhiza 10. 175-183.

LALOR, B.M., COOKSON W.R. \& MurPhy, D.W. 2007. Comparison of two methods that assess soil community level physiological profiles in a forest ecosystem. Soil Biol. Biochem. 39. 454-462.

Landwehr, M., Hildebrandt, U., Wilde, P., Nawrath, K., Tóth, T., Biró, B. \& HERMANN, B. 2002.The arbuscular mycorrhizal fungus Glomus geosporum in European saline, sodic and gypsum soils. Mycorrhiza 12. 199-211.

OKsanen, J., Blanchet, F.G., Roeland, K., Legendre, P., Minchin, P.R., O’Hara, R.B.,

Simpson, G.L., Solymos, P., Stevens, M.H.H. \& WAGneR, H. 2014. vegan: Community ecology package. R package version 2.2-0. R Foundation for Statistical Computing, Vienna, Austria. 
PHILLIPS, J.M. \& HAYMAN, D. S. 1970. Improved procedures for clearing roots and staining parasitic and vesicular-arbuscular mycorrhizal fungi for rapid assessment of infection. Trans. Brit. Mycol. Soc. 55. 157-160.

RusznYák, A., Vladár, P., Szabó, G., Márialigeti, K. \& Borsodi, A.K. 2008. Phylogenetic and metabolic bacterial diversity of Phragmites australis periphyton communities in two Hungarian soda ponds. Extremophiles 12. 763-773.

Szabó, G., Borsodi, A., Vladár, P., Cech, G., Tóth, E., Boros, E. \& Márialigeti, K. 2004. A Kiskunsági Nemzeti Park szikes tavainak bakteriológiai vizsgálata. Hidrol Közl 84. $147-150$.

SMITH,S.E. \& SMITH, F.A., 2011. Roles of arbuscular mycorrhizas in plant nutrition and growth: New paradigms from cellular to ecosystem scales. Annual Review of Plant Biology 62. 227-250.

SzILI-KovÁCS, T. \& TÖRÖK, K., 2005. Szénforráskezelés hatása a talaj mikrobiális aktivitására és biomasszájára felhagyott homoki szántókon. Agrokémia és Talajtan 54. 149-162.

Tóth, T. \& SzENDREI, G. 2006: A hazai szikes talajok és a szikesedés, valamint a sófelhalmozódási folyamatok rövid jellemzése. Topographia Mineralogica Hung. 9. 7-20.

Trouvelot, A., Kough, J.L. \& Gianinazzi-PeArson, V. 1986. Mesure du taux de mycorhization VA d'un système radiculaire. Recherches et methods d'estimation ayant une signification fonctionnelle. In: Gianinazzi-Pearson, V. \& Gianinazzi, S. eds., Physiological and genetical aspects of mycorrhizae. INRA, Paris, 217-221.

van der Heijden, M.G.A., Klironomos, J.N., Ursic, M., Moutoglis, P., StreitwolfEngel, R., Boller, T., Wiemken, A. \& SANDERS, I.R., 1998. Mycorrhizal fungal diversity determines plant biodiversity, ecosystem variability and productivity. Nature 396. 69-72.

Wakelin, S. A., Macdonald, L. M., Rogers, S. L., GregG, A. L., Bolger, T. P. \& BALDOCK, J. A. 2008. Habitat selective factors influencing the structural composition and functional capacity of microbial communities in agricultural soils. Soil Biol. Biochem. 40. 803-813.

West, A. W. \& Sparling, G. P. 1986. Modifications to the substrate-induced respiration method to permit measurement of microbial biomass in soils of different water contents. J. Microbiol. Meth. 5. 177-189.

ZaK, J. C., Willig, M.R., MoOrhead, D.L. \& WildMan, H.G. 1994. Functional diversity of microbial communities: a quantitative approach. Soil Biol. Biochem. 26. 1101-1108. 


\title{
Analysis of the microbial metabolic activity patterns and mycorrhizal fungal colonisation in the rhizosphere of three soils neighbouring sodic lakes
}

\author{
${ }^{1}$ T. SzILI-KovÁCs, ${ }^{2}$ Á. BÁRÁnY, ${ }^{1}$ A. FÜZY, ${ }^{1}$ T. TAKÁCS, ${ }^{1,2}$ G. KRETT, ${ }^{1}$ R. KovÁCs and \\ ${ }^{2}$ A. BORSODI \\ ${ }^{1}$ Research Institute for Soil Sciences and Agricultural Chemistry, Centre for Agricultural \\ Research, MTA, Budapest \\ ${ }^{2}$ Eötvös Loránd University, Department of Microbiology, Budapest
}

\section{Summary}

Adaptation of organisms to the extreme water regime, salt content and alkalinity characterized by saline-sodic soils is a great challenge. We have compared the catabolic activity patterns of soil microbial communities of the rhizosphere at three soda ponds, Böddi-szék, Kelemen-szék and Zab-szék from the sediment of the lake through others vegetation to the sodic pasture. It was assumed that differences in soil sodicity and vegetation characteristics would affect soil microbial community. The preliminary results showed that the samples from different locations could be divided by their substrate utilization patterns. The soil basal respiration was correlated primarily with the soil organic carbon. The soil community level catabolic profiles were significantly affected by soil $\mathrm{pH}$ and EC by gas chromatographic SIR with 5 substrates while by $\mathrm{pH}$ and humus content by microrespiration using 15 substrates. Arbuscular mycorrhizal (AM) fungal colonization have essential role in the survival of plants in habitats characterized by extreme soil conditions, as in the salt-affected soils. Large difference was found between the two dominant plant species sea aster (Tripolium pannonicum) and alkali grass (Puccinellia limosa) in the AM fungal colonization characteristics, showing a much stronger colonization by the previous one. The AM fungal colonization of the same plant species was different at the three sites, which could not be explained by the soil properties.

Keywords: AM fungi, Microresp, soil respiration, substrate induced respiration

Table 1. Samling sites of the soil samples. (1) Sample site (2) Code of the sample (3) Geographical location of the samples in WGS84 system (4) Type of sample, vegetation: (a) sediment of the pond; (b) Bolboschoenus sp. (c) Puccinellia sp.; (c/d) Puccinellia/Tripolium; (e) sodic grassland, mainly Festuca

Table 2. Soil properties. (1) Code of sample; (2) Sand\%; (3) Silt\%; (4) Clay\%; (5) Humus-content $\%=$ soil organic $\mathrm{C}$ x 1.725 .

Table 3. Means \pm (standard deviation) with significant differences with different letters among substrate induced respiration values of soil samples measured by gas chromatography 
( $\mathrm{p}<0.05$ ). (1) Code of sample; (2) D-Glucose; (3) Succinate; (4) L-Arabinose; (5) Trehalose; (6) D-Fructose.

Table 4. Correlation and significance of the vector fitting of the environmental variables (Humus content, $\mathrm{pH}, \mathrm{EC}$, sand-, silt- and clay content) on the ordination diagram.

Figure 1. Mean values of basal respiration (with standard deviations) of pond sediments (B15, K18, and Z22) and soil samples measured by gas chromatography.

Figure 2. Comparison of the substrate induced respiration from the same samples measured by gas chromatograpy (a) and microrespiration (b) with 5 substrates.

Figure 3. Graphical plot of the principal coordinate analysis (PCoA) of SIR measured by gas chromatography with 5 substrates with fitting on the environmantal variables (humus content, $\mathrm{pH}$, and electrical conductivity (EC), and silt content.

Figure 4. Graphical plot of the principal coordinate analysis (PCoA) of SIR measured by MicroResp with 15 substrates with fitting on the environmantal variables (humus content, $\mathrm{pH}$, and electrical conductivity (EC), and silt content.

Figure 5. Arbuscular mycorrhizal root colonization characteristics of the Tripolium pannonicum and Puccinellia limosa at the three sampling sites (M\%: intensity of the root colonization; A\%: arbuscular richness). 